\title{
Analysis on Cultural Creative Professional Group Curriculum under the Applied Transformation
}

\author{
Meichiao Lai \\ Fuzhou University of International Studies and Trade \\ Fuzhou, China 350202
}

\author{
Wuder Tsay \\ Fuzhou University of International Studies and Trade \\ Fuzhou, China 350202
}

\author{
Yan Lin \\ Fuzhou University of International Studies and Trade \\ Fuzhou, China 350202
}

\begin{abstract}
This thesis aims to explore the construction of cultural creative professional course. Thesis structure is based on international education certification norms, including the exploration of curriculum problems, vision and educational goals, curriculum construction, curriculum design and teaching effectiveness, curriculum continuous evaluation and improvement. This study is based on the reform of Chinese scholars and experts, following the model of international education theory and citing the experience of higher education in Taiwan. The results are expressed in three graphs and three tables, highlighting the overall context and relevance of curriculum reform in order to promote the quality of education in line with international education certification norms, and become a new pattern of applied curriculum with Chinese characteristics.
\end{abstract}

Keywords-curriculum reconstruction; cultural creative professional group; applied transformation

\section{INTRODUCTION}

Facing the national policy requirements to develop undergraduate colleges and transfer them into the applied type, so the curriculum reform is an inevitable trend. How to reconstruct the curriculum to train the applied talents has become an important issue. The key factor of the success of applied reconstruction lies in the policy effect of the government, the way of enterprise's participation and the transformation way of different universities. The core problem lies in the curriculum re-construction. 。

The inherent characteristics of cultural and creative courses are original design, self-made works and practicality experiential courses. However, as Xiamen University Wang Naikao pointed out that "many colleges and universities set up a professional curriculum system, is the 'culture + industry + management'. Based on the patched up courses, patched up teacher lessons, and the theory class, after graduation, how to cultivate the students who can meet the needs of Regional economic industry employment? The purpose of this article is to explore the teaching problems of the cultural creative courses, sorting out the important theories and models of

Fund Project: the phased research results of the key project of Fujian Provincial Social Science Plan "Study on Coupling And Symbiosis Of Professional Groups and Regional Industrial Groups under the Transformation from Undergraduate Universities to Applied Type" (Project number: FJ2016A014). related courses domestic and overseas, and putting forward the new methods for outstanding applied solutions.

Based on the rapid development of China's economy, the demand for cultural and creative talents has changed. The demands transformation is appeared from the industrial restructuring, technological upgrading and so on. That source, which can provide cultural and creative talents, has changed in the school system, professional construction, teaching mode, personnel training, teacher team building, and management service model and so on. From the value chain perspective, university education and regional industries each have their own core functions. Between the two systems, the purpose is to identify new features of cooperation and innovation, resulting in value-added. Systematic structure diagram contains: reasons, problems, structural changes, opportunities and paths, structural changes, countermeasures, innovation, as shown below "Table I".

TABLE I. CURriculum OF CUltural AND CREATIVE ProfessionAL GROUP

\begin{tabular}{|c|c|c|c|}
\hline Reason & Problem & \multicolumn{2}{|c|}{ Opportunities and Paths } \\
\hline $\begin{array}{l}\text { Industrial change, } \\
\text { scientific } \\
\text { technological and } \\
\text { progress, } \\
\text { innovation, gap } \\
\begin{array}{l}\text { between learning } \\
\text { and using }\end{array}\end{array}$ & $\begin{array}{l}\text { talented } \\
\text { person's } \\
\text { imbalance } \\
\text { between } \\
\text { demand and } \\
\text { supply, wrong } \\
\text { docking } \\
\end{array}$ & \multicolumn{2}{|c|}{$\begin{array}{l}\text { government guidance, industry } \\
\text { participation, school conscious } \\
\text { tranformation, } \\
\text { transformation from service to } \\
\text { application }\end{array}$} \\
\hline $\begin{array}{c}\text { Structural } \\
\text { transformation }\end{array}$ & $\begin{array}{c}\text { Countermeasu } \\
\text { res }\end{array}$ & $\begin{array}{c}\text { Innovation } \\
\text { combination of } \\
\text { education and } \\
\text { indusry }\end{array}$ & \multirow[b]{2}{*}{$\begin{array}{l}\text { Cultural and } \\
\text { creative } \\
\text { talents can } \\
\text { meet local } \\
\text { economic } \\
\text { needs, and } \\
\text { obtain the } \\
\text { international } \\
\text { education } \\
\text { authenticatio } \\
n\end{array}$} \\
\hline $\begin{array}{l}\text { Changing of } \\
\text { Industrial } \\
\text { Ecosystem, } \\
\text { Increasing } \\
\text { application of talent } \\
\text { needs, } \\
\text { Reversaling of } \\
\text { Teachers' Teaching, } \\
\text { Updating Teaching } \\
\text { Materials of } \\
\text { Production and } \\
\text { Teaching }\end{array}$ & $\begin{array}{l}\text { Schools and } \\
\text { cultural } \\
\text { innovation } \\
\text { industry's } \\
\text { development } \\
\text { fit, connect, } \\
\text { communicate, } \\
\text { contact with } \\
\text { each other to } \\
\text { achieve } \\
\text { common } \\
\text { development }\end{array}$ & $\begin{array}{l}\underset{\text { University }}{\text { education }} \\
\text { eduction }\end{array}$ & \\
\hline
\end{tabular}




\section{Vision AND EdUCATIONAL GOALS - PROBLEM SOLVING STRATEGIES}

The transformation from undergraduate colleges to applied ones is actually a kind of innovation, which includes all kinds of reforms in school education, bringing new ideas, new things and new challenges. This innovative construction program cultural creative professional group courses is a new five-year reform of the new construction program, from the organization and leadership to all units of the school. The Vision is to make the curriculum to achieve international evaluation standards and become a curriculum construction with Chinese characteristics, based on Wu Yan's point of view, concerning about the quality of education and quality assurance, developing of certification tools suited to national conditions. $\mathrm{Wu}$ Yan is a director of the Center for Higher Education Teaching Evaluation of the Ministry of Education.

The goals and ideas are based on the view of Gu Cuifeng, Wang Luyuan's remarks on The fusion development strategy of international production and education forum "The autonomy, standardization and ecosystem of applied technology university the construction". The autonomy principle is the motivation for applied technology university construction, providing the initiative, leading and decisionmaking power for the initiative transformation and independent development of colleges and universities .The normative principle promotes the transformation of organizational operation, the principle of ecology emphasizes on the long - term system balance.

\section{THE CONSTRUCTION OF CURRICULUM AND THE CONSTRUCTION PLAN}

Cultural and creative professional group is the art profession, in accordance with the state in 2012 promulgated undergraduate professional directory level discipline. The professional (Level 2)1303 Theater and Film and Television Arts, 1304 Fine Arts, 1305 Design (Arts and Engineering), and Creative Arts, which consists of animation, radio and television choreographer, arts profession, clothing and costume design (engineering) Profession composition, and by the arts, engineering and other disciplines cross and support. The relationship among the cultural and creative professional group curriculum construction program and professional construction and also the industry group as shown in below "Table II".

TABLE II. CUltural AND CREATIVE PROFESSIONS CURRICUluM CONSTRUCTION PROGRAM

\begin{tabular}{|l|l|l|}
\hline $\begin{array}{l}\text { School discipline } \\
\text { construction } \\
\text { literature and art } \\
\text { manages } \\
\text { economic and } \\
\text { engineering }\end{array}$ & $\begin{array}{l}\text { the cross } \\
\text { among } \\
\text { cultural } \\
\text { creative } \\
\text { professional } \\
\text { group, art } \\
\text { and } \\
\text { engineering } \\
\text { subjects }\end{array}$ & $\begin{array}{l}\text { Specialty construction is } \\
\text { comprehensive, including disciplinary } \\
\text { direction, scientific research, } \\
\text { personnel training, academic team, } \\
\text { and academic exchanges. Specialty } \\
\text { construction is the combination of } \\
\text { teaching, scientific research and } \\
\text { personnel training. The aim is to } \\
\text { improve the competitiveness of the } \\
\text { school rankings, to expand social } \\
\text { influence and visibility. Breakthrough } \\
\text { refers to scientific research projects, } \\
\text { quality courses, degrees, key } \\
\text { disciplines, key laboratories, national }\end{array}$ \\
& \multicolumn{2}{|l}{}
\end{tabular}

\begin{tabular}{|c|c|c|}
\hline & & teaching masters, excellent papers. \\
\hline $\begin{array}{l}\text { Application } \\
\text { group } \\
5 \quad \text { professional } \\
\text { groups }\end{array}$ & $\begin{array}{l}\text { the } \\
\text { combination } \\
\text { of cultural } \\
\text { creative } \\
\text { professional } \\
\text { groups }\end{array}$ & $\begin{array}{l}\text { Profession group construction, after } \\
\text { all, is different from the subject } \\
\text { construction and profession } \\
\text { construction. It needs the support and } \\
\text { integration from many specialties. } \\
\text { Profession group construction is the } \\
\text { need to combine regional industries, at } \\
\text { the same time, the employment of } \\
\text { students should also link specialties. } \\
\text { Profession group construction should } \\
\text { be timely adjustment of profession } \\
\text { and profession group structure, to } \\
\text { promote profession vertical and } \\
\text { horizontal development, to match the } \\
\text { development of social economy } \\
\text { construction , and to reform } \\
\text { profession group connotation. }\end{array}$ \\
\hline $\begin{array}{l}11 \text { faculties } \\
4 \text { departments }\end{array}$ & \multirow{4}{*}{$\begin{array}{l}\text { animation, } \\
\text { radio and } \\
\text { television } \\
\text { choreograph } \\
\text { er, arts } \\
\text { profession, } \\
\text { clothing and } \\
\text { apparel } \\
\text { design }\end{array}$} & \multirow{4}{*}{$\begin{array}{l}\text { The construction of specialty is } \\
\text { oriented to the needs of social and } \\
\text { economic development and industrial } \\
\text { structure adjustment. Students' } \\
\text { training and the employment direction } \\
\text { of graduates are taken into } \\
\text { consideration, which directly affects } \\
\text { the enrollment and teaching } \\
\text { infrastructure. It is based on the } \\
\text { quality of teaching as the goal; it is the } \\
\text { core of personnel training model and } \\
\text { curriculum construction. The content } \\
\text { of professional construction includes } \\
\text { the development of professional } \\
\text { training objectives and specifications, } \\
\text { the development of teaching plans, } \\
\text { professional settings, teaching } \\
\text { materials and teaching reform. It does } \\
\text { not belong to the scope of discipline } \\
\text { construction, isn't the subject } \\
\text { construction content. }\end{array}$} \\
\hline & & \\
\hline $\begin{array}{l}\text { Profession } \\
\text { construction }\end{array}$ & & \\
\hline 25 professions & & \\
\hline $\begin{array}{l}\text { Profession } \\
\text { supply chain } \\
\text { Upstream: } \\
\text { Vocational } \\
\text { secondary } \\
\text { professional } \\
\text { disciplines } \\
\text { Middle: } \\
\text { Undergraduate } \\
\text { Education } \\
\text { Downstream: } \\
\text { industrial clusters } \\
\text { and cross-domain }\end{array}$ & $\begin{array}{l}\text { cultural } \\
\text { creative } \\
\text { professional } \\
\text { industry } \\
\text { group }\end{array}$ & $\begin{array}{l}\text { Industrial cluster effect refers to } \\
\text { enterprises in the form of new space } \\
\text { economic organization; through the } \\
\text { network closely linked together in a } \\
\text { certain region within a specific } \\
\text { industry have a number of divisions of } \\
\text { labor relations. } \\
\text { Fujian will be the first to promote the } \\
\text { business, communications, tourism, } \\
\text { entertainment and cultural industries, } \\
\text { strengthen the docking of Taiwan's } \\
\text { economy, society and culture, expand } \\
\text { market openness, and promote the } \\
\text { cooperation mechanism of policy } \\
\text { innovation. } \\
\text { Professional group and industrial } \\
\text { cluster fusion effect is the educational } \\
\text { courses, the spirit of the supply chain } \\
\text { from upstream, midstream and } \\
\text { downstream trinity. When these three } \\
\text { aspects professional courses formulate } \\
\text { development construction, this } \\
\text { solution can connect the profession } \\
\text { and industry relationship, forming into } \\
\text { the academic group, professional } \\
\text { group fused to the industrial chain, } \\
\text { promoting the technology skilled } \\
\text { talents systematic cultivation ability } \\
\text { and level. }\end{array}$ \\
\hline
\end{tabular}




\section{The Courses Design Method And Teaching RESULTS}

The course design thoughts is refer to the design educational certification standards requirements, profession and implementation settings has more than three-eight proportion of the lowest graduate credit. Therein, the design implementation courses have one-four proportion of the lowest graduate credit. To use the capstone general course concept to supervise if the students learning of Integrate skills, knowledge and situation, practical ability and output results can meet with the industry requirements or not. The standards formulation of cultural creative professional group talent cultivation is made by mainly four measures: demand research, training standards, quality assessment, professional certification, based on deepening strategy of the integration between production and learning, its solution is continuously deepening with animation, radio, television playwright-director, fine arts, clothing and dress design majors professional group to conduct the applied type talents training mode reform, combining with the characteristics of each major features, roundly to revise the talent training scheme. Actively to explore the universityenterprise joint training, "modern apprenticeship, using cooperation between Fujian and Taiwan cultivation diversified personnel training mode, etc. The colleges and enterprises two institutions together develop the college and enterprise combination model, focusing on the professional group combined with industrial clusters, from the supply side to make the school running characteristics, curriculum standards applied talents, and in industry demand side, dealing with the regional industrial clusters, industry professional duties, talent using organizations job employment application ability, further cooperation, respectively, including the curriculum system reconstruction and fusion education (including strengthening shared resources, deepen the professional and cross domain), reform of teaching and learning mode (including teachers further study, students cultivation), industry-education integration, teaching, cooperative education mechanism. Which is accord with the deepening reformation of vocational education teaching, so as to promote the employment as the guidance, to adapt to the economic development requirements of the new normal and technical skills talents, to improve the integration between production and education, to enhance students' employment ability as the core, to strengthen ideological and moral, cultural literacy education and technical skills training, comprehensively improving the quality of personnel training.

\section{COURSE CONTINUOUS ASSESSMENT AND IMPROVEMENT}

Using the course assessment model (context, input, process, product, CIPP), based on the With industry and education meeting continuously scheduled and modify a group of professional courses, Curriculum evaluation including the graduates profession suit rate, high employment rate, high starting salary, high enterprise satisfaction, and high social evaluation ( 4 highs) as the main index in the talent training quality assessment. To absorb employer units to take part into the whole teach dynamic supervising, analyzing and the teaching quality evaluation. Make the talent training quality to achieve the society, employer, students, parents, school satisfaction. So as to coordinate CIPP based each subsystem orderly running, making the whole system functioning as bellow "Table III"

TABLE III. CONTINUOUSLY IMPROVING THE CIPP BASED COURSES ASSESSMENT MODEL

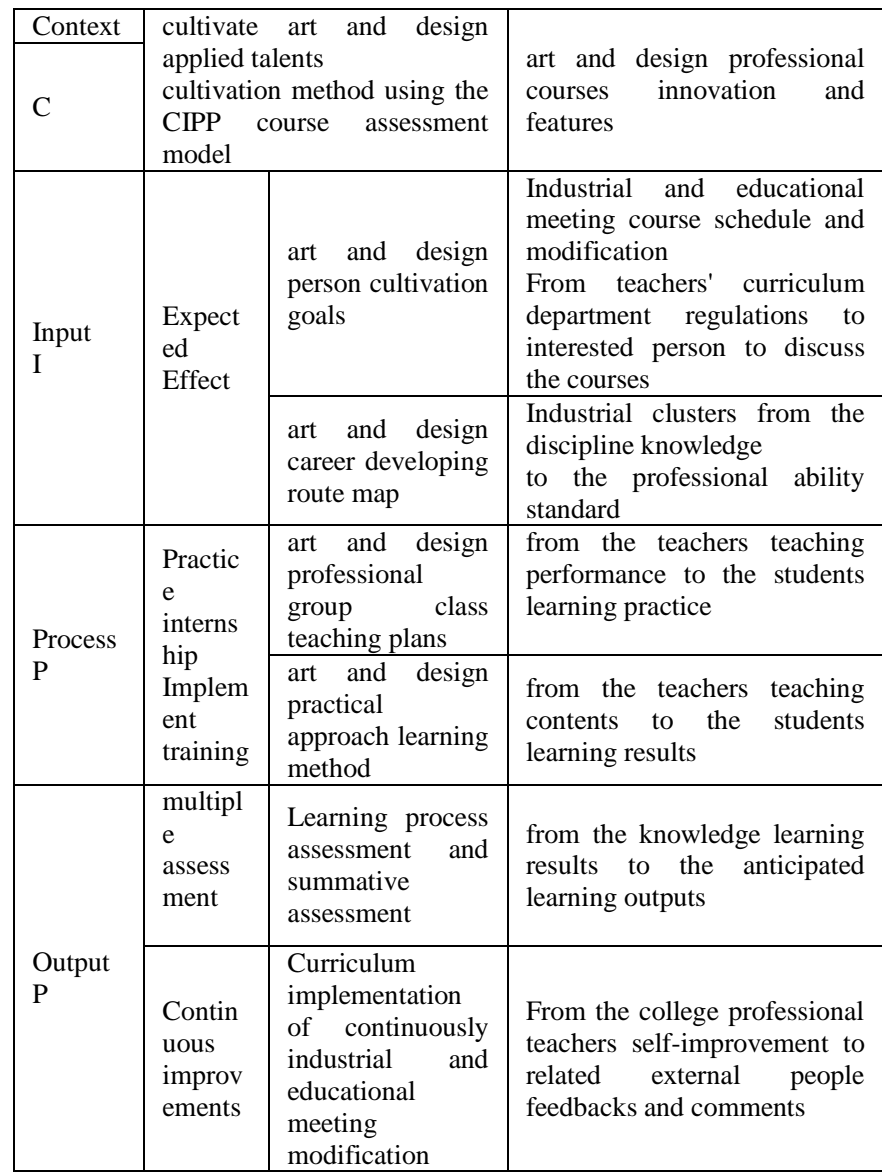

\section{CONCLUSION}

In conclusion, curriculum reform is influenced by the policy deployment, enterprise participation, school leaders leading, and the staff's carry out and other factors, applied technical transformation construction is related to the highlevel professional and technical personnel training, the critical success factor lies in the government policy effect and enterprises participating models and the different universities reforming forms, the core problem is the course reconstruction and reformation.

This thesis borrows certain international courses reforming new concept and method and the Taiwan college experience, using the systematic exploration for cultural creative professional curriculum issues, then supplying the cultural creative professional group curriculum construction scheme, then to response to the culture and design professional group talents cultivation scheme, the last to continuously improve the CIPP based course assessment model. 


\section{REFERENCES}

[1] Guo-Li Xu(2016).An Exploration on Promoting Collaboration of Cultural Creative Industry between Fujian and Taiwan. Proceeding of the 2nd Internationa Conference of Arts, Design and Contemporary Education.

[2] Li-Ya Lin, Guo-Chao Lin(2016).Project Management for Cultura 1 and Creative Goods. Proceeding of the 2nd Internationa Conference of Arts, Design and Contemporary Education.

[3] Jie Zhu(2016). An Exploration on Connecting Industry Clusters with Educational Professional Group. Proceeding of the 2nd International Conference of Arts, Design, and Contemporary Education .

[4] Zhe-Lin Zheng(2016). A Case Study on Design a Culture Creative Product Base on Value Creation Principle. Proceeding of the 2nd Internationa Conference of Arts, Design, and Contemporary Education.

[5] Zu-Jiang Ji, Yuan-Ling Chen(2016). When and How Does Collections of Creative's Lead to Creatives? Proceeding of the 2nd Internationa Conference of Arts, Design, and Contemporary Education.

[6] Luo Xiaoyan. Research of Yunnan Xishuangbanna higher vocational education entrepreneurial talent training mode. [D]. Yunan Colleage.2015.

[7] Li Xu. Theory of Henan local undergraduate university fine arts major applied talents cultivating training mode construction $[\mathrm{J}]$. Educational Forum.2014 (03).

[8] Li Maodan. The survival and development of the traditional fine arts in the applied undergraduate universities $[\mathrm{J}]$. Tong Ling College Journal.2014 (01).

[9] Xie Maokang. The research of vocational education professional group based on the construction viewpoints --- Hunan undertaking industrial transfer demonstration area as an example $[\mathrm{J}]$. Vocational Education Study. 2016 (07). 